\title{
THE ELABORATION OF INDICES TO ASSESS BIOLOGICAL WATER QUALITY. A CASE STUDY
}

\author{
M. A. S. GRAÇA' and C. N. COIMBRA' \\ 'Departamento de Zoologia, Universidade de Coimbra, 3000 Coimbra, Portugal
}

(First received March 1996; accepted in revised form August 1997)

\begin{abstract}
Here we tested the application of a nodal analysis for the elaboration of biotic indices for particular stressing conditions. The work was carried out in an intermittent Mediterranean stream where superficial flow was absent during summer. The river was perturbed by an effuent with high $\mathrm{pH}$, sulphates, nitrates and conductivity. "Summer" and "winter" samples were treated separately. We first identified groups of sites differing in taxonomical composition by cluster analysis. Then we tested whether groups of sites also differed in their abiotic characteristics. In the following step, groups of cooccurring taxa were also identified by cluster analysis. The indicator value of a taxa group was measured by fidelity measurements for site groups. Indicator taxa were incorporated in a water quality table. The biotic index in the water quality table clearly discriminated impacted from reference sites in the two following years and was correlated with the first axis of a correspondence analysis biplot which also discriminated impacted from clean sites. We suggest that nodal analysis can be a reliable technique for the identification of bioindicators and the elaboration of biotic indices. (C) 1998 Elsevier Science Ltd. All rights reserved
\end{abstract}

Key words $\longleftarrow$-Biological indices, water quality, bioindicators, temporary rivers

\section{INTRODUCTION}

Biotic indices are numerical expressions coded according to the presence of bioindicators differing in their sensitivity to environmental conditions. They have been used in Europe for several decades for routine rapid assessment of water quality in rivers (for reviews, see Washington, 1984; Metcalfe, 1989). The most popular indicators have been algae, particularly diatoms (e.g. the CEC index; Descy and Coste, 1991) and macroinvertebrates (e.g. Indice Biologique de Qualitè Genèrale-IBGVerneaux et al., 1982; Belgian Biotic Index-BBIDe Pauw and Vanhooren, 1983).

Indices developed for a particular zone have been applied, apparently with success, in other geographical areas. This is the case of BBI, developed for Belgium, applied in Portugal (Fontoura and Moura, 1984), Indonesia (Krystiano and Kusjantono, 1991), Canada (Barton and MetcalfeSmith, 1992) and other areas (De Pauw et al., 1986). However, the application of biological indices for environmental conditions or pollution types other than the ones where they were developed for it may be questionable (e.g. Coimbra and Graça, in press). Therefore, the adoption of an index needs to be preceded by pilot studies and validation by the application of multivariate analysis technics (e.g. Moreira et al., 1988a,b) or by the alteration of the

*Author to whom all correspondence should be addressed. original scores of indicator taxa (e.g., AlbaTercedor and Sánchez-Ortega, 1988).

In a previous work, Coimbra et al. (1996) showed that several indices currently used to assess water quality elsewhere were useless in Mediterranean rivers at South Portugal where the superficial flow is interrupted during half of the year. In that study, several biotic indices were unable to discriminate sites polluted by a high $\mathrm{pH}$ effluent from reference sites, during flowing conditions. In summer, when the superficial flow was absent, none of the tested methods differentiated polluted from clean sites. This suggests that if we are going to adopt biotic indices in monitoring programs, they have to be developed according to local conditions. However, no rules have yet been established for the identification of indicator taxa or for the elaboration of the indices themselves. The aim of this work was to test the application of nodal analysis (sensu Boesch, 1977) for the identification of indicators of particular environmental conditions and integrate them in a biotic index.

\section{MATERIAL AND METHODS}

\section{Biological and chemical sampling}

Macroinvertebrates were sampled four times a year (1st week of February, May, August and November in 1991 and 1992) along a river receiving an industrial effluent with high $\mathrm{pH}$, conductivity, sulphates and nitrates and low oxygen at Alentejo, South Portugal. Samples were collected along eight sites below the effluent output ( 0 to 7$)$ 
and in eight reference sites: six were located along the same river (R1-R6) and two in two unpolluted nearby rivers ( $R C 1$ and RV1). At each sampling occasion, dissolved oxygen and water temperature were measured in situ with a portable meter. One liter of water was also collected for other physico-chemical determinations in the laboratory: $\mathrm{pH}$, conductivity (specific meters), sulphates, nitrates, phosphates, copper and iron (A.P.H.A., 1980).

As in many rivers of the region, superficial flow occurs only during approximately six months in a year, from the end of autumn to the beginning of spring (median river discharge during flowing conditions between 1992 and $1996=60 \mathrm{~L} / \mathrm{s}$, with peak values of $>374 \mathrm{~L} / \mathrm{s}$ ). During the rest of the year, the superficial flow is absent and the river is reduced to a succession of ponds differing in size (up to several hundreds of square meters in area and $1.5 \mathrm{~m}$ deep).

As a consequence of the seasonality of the rain fall, the river topography is heterogeneous: pools may be followed by riffles; the substrate may be dominated by sand, pebbles or large rocks; aquatic plants may be absent or cover completely the river bottorn; trees are normally absent from the stream margin, but the benthic organic matter is conspicuous, resulting mainly from the decay of aquatic plants.

This habitat and seasonal heterogeneity did not allow rigorous quantitative sampling with traditional quantitative devices such as Hess, Surber or Ekman samplers. Therefore, a semi-quantitative kick-and-sweep technique was applied using a hand net $(0.3 \times 0.3 \mathrm{~m}$ wide and $0.5 \mathrm{~mm}$ mesh size). At each sampling site six sample replicates were collected in the major macrohabitats, each covering a distance of approximately $1 \mathrm{~m}$. Samples were transported to the laboratory and the specimens sorted alive and preserved in $70 \%$ ethanol for further identification to the highest possible taxonomical level. This was in general species (e.g., Plecoptera) or genus (e.g., Coleoptera) and in some cases only to family (e.g. Diptera) or to sub-family (Chironomidae).

Because of the remarkable differences in environmental conditions in the lotic period (February and May) and in the lentic period (August and November), hereafter referred as "winter" and "summer" periods respectively, data from both "seasons" were treated separately.

\section{The identification of indicator groups}

Two matrices of taxa $\times$ samples were produced, one for each, the lotic and the lentic conditions. Only taxa with an occurrence higher than 20 individuals were considered $(=45$ and 51 taxa for "winter" and "summer" data sets respectively).

Co-occurrence relationships among taxa were investigated by the application of the product-moment correlation coefficient (Zar, 1984). Dissimilarity relationships among sampling sites were quantified by the Bray and Curtis coefficient (Boesch, 1977; Faith et al., 1987), after a $\log _{10}(x+1)$ transformation. The resulting symmetric matrices were subjected to cluster analysis (UPGMA Legendre and Legendre, 1979) in Q mode (sample grouping) and in $\mathrm{R}$ mode (taxa grouping).

Taxa and sample groups obtained by cluster analyses were related by a nodal analysis (Boesch, 1977). This relation was established by a fidelity index which measures the association of a determined group of taxa for a particular group of sites, according to the expression (Boesch, 1977):

Table 1. Water quality categories and bioindicators for the Alentejan Mediterranean river

\begin{tabular}{|c|c|c|}
\hline $\begin{array}{l}\text { LOTIC CONDITIONS } \\
\text { ("winter") }\end{array}$ & Brotic INDEx & $\begin{array}{l}\text { LENTIC CONDITIONS } \\
\text { ("ganer") }\end{array}$ \\
\hline \multirow{2}{*}{$\begin{array}{l}\text { PRISENCE OF: } \\
\text { Ectyomunus, Ephemenella, } \\
\text { Leptophlebiidae, Plocoptera or } \\
\text { Oulimnius. }\end{array}$} & \multirow{2}{*}{$\begin{array}{l}\text { CLEAN CONDITIONS } \\
\text { (INDEX VALUE = 5) }\end{array}$} & $\begin{array}{l}\text { PRTSENCE OF: } \\
\text { Loptophlebiidea. }\end{array}$ \\
\hline & & \multirow{2}{*}{ 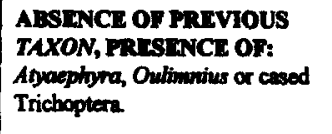 } \\
\hline \multirow[b]{2}{*}{$\begin{array}{l}\text { ABSENCK OF PRRVIOUS } \\
\text { TAXA, PRESENCR OF: } \\
\text { Bithynia, Hydracarina, } \\
\text { Atyaephyra, Bactidae, Caenis, } \\
\text { Platycmemis or Trichoptera. }\end{array}$} & \multirow[b]{2}{*}{$\begin{array}{l}\text { MILD STRESSING } \\
\text { CONDMTONS } \\
\text { (INDEX VALUE = 4) }\end{array}$} & \\
\hline & & 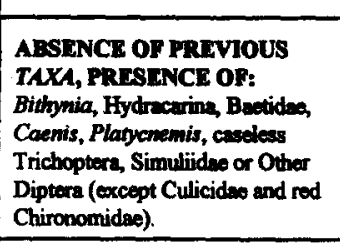 \\
\hline $\begin{array}{l}\text { ABSENCE OF PREVIOUS } \\
\text { TAXA, PRESENCE OF: } \\
\text { Physa, Coenagrionidae or } \\
\text { Libellulidae. }\end{array}$ & $\begin{array}{l}\text { INTERMEDUTE STRESSING } \\
\text { CONDITONS } \\
\text { (INDEX VALUE = 3) }\end{array}$ & \multirow{2}{*}{ 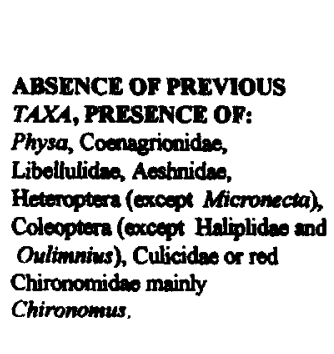 } \\
\hline $\begin{array}{l}\text { ABSENCE OF PREVIOUS } \\
\text { TAXA, PRESENCE OF: } \\
\text { Berosus, Culicidao or red } \\
\text { Chironomidwe mainly } \\
\text { Chironomus. }\end{array}$ & $\begin{array}{l}\text { STRONG STRESSING } \\
\text { CONDITIONS } \\
(\text { INDEX VALUE = 2) }\end{array}$ & \\
\hline $\begin{array}{l}\text { ABSENCE OF } \\
\text { MACROINVERTEBRATES } \\
\text { (or preace lower then } 5 \\
\text { individualy). }\end{array}$ & $\begin{array}{l}\text { EXTREME CONDrTIONS } \\
\text { (INDEX VALUL }=1 \text { ) }\end{array}$ & $\begin{array}{l}\text { ABSENCE OF } \\
\text { MACROINVERTEBRATES (or } \\
\text { presence lower then } 5 \\
\text { ivolividual). }\end{array}$ \\
\hline
\end{tabular}




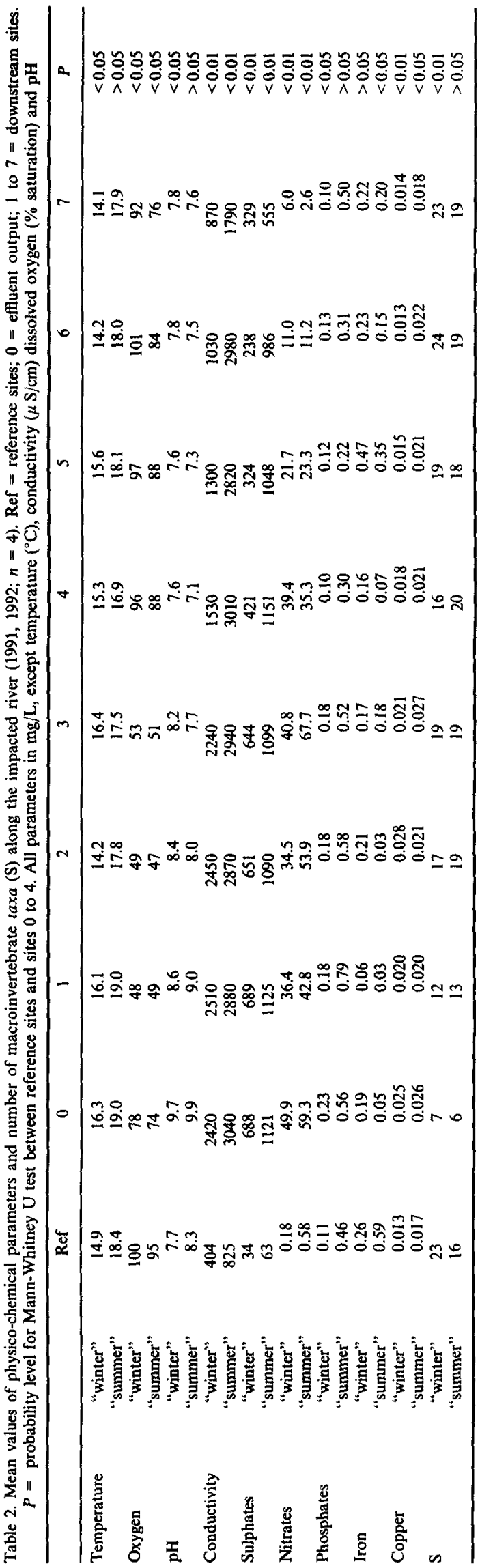

$$
F_{\mathrm{ij}}=\left(a_{\mathrm{ij}} \sum_{\mathrm{j}} n_{\mathrm{i}}\right) /\left(n_{\mathrm{j}} \sum_{\mathrm{j}} a_{\mathrm{ij}}\right)
$$

$\left(\mathrm{a}_{\mathrm{ij}}=\right.$ total number of occurrences of the $i$ taxa group in the $j$ site group; $n_{\mathrm{i}}$ and $n_{\mathrm{j}}=$ respectively the total number of taxa in the taxa group $i$ and the total number of sites in the site group $j$ )

Four fidelity categories were considered: $\geq 3,2-2.9,1-$ 1.9 and $<1$, which correspond to high, moderate, low and negative fidelity respectively. Negative fidelity suggests a "fugitive" reaction of taxa from conditions in a determinate group of sites. Values higher than two suggest that the taxa are favoured by the dominant conditions in the sampling sites group.

To be considered as an indicator in the standard biotic index table (see below), a particular taxon has to meet two criteria:

(a) groups of organisms with high/moderate or negative fidelity for groups of samples, were considered bioindicators of the particular chemical and physical conditions in the sites where samples were collected. It was assumed that all reference sites were not polluted because the absence of villages, industries or other visible sources of pollution. Moreover, agricultural activities in the area were inconspicuous.

(b) the potential indicators obtained according to the previous criterion should be always present. Species with occasional occurrence were eliminated. This was tested by inspection of the original data matrices.

Bioindicators were ordered in a double entrance table according to the hydrological condition (vertical entrance) and to the tolerance level to the stressing conditions (horizontal entrance)-see below; Table 1.

Assessing the biological water quality using the Biotic Index

To assess the biological water quality, a sample is taken as previously described: using a hand net $(0.3 \times 0.3 \mathrm{~m}$ wide; $0.5 \mathrm{~mm}$ mesh size), six sample units are taken using the "kick method" when current is present or the "kickand-sweep method" when the river has no flow. Each sample unit should cover a distance of approximately $1 \mathrm{~m}$ and sample units should be taken in all major macrohabitats according to their proportion in the river (e.g. if $50 \%$ of a study sector is covered by submersed plants and $50 \%$ correspond to a substrate covered by pebbles, three sample units should be taken in each macrohabitat).

The cumulative biological sample should be observed after remotion of sand and detritus.

The standard table for the biotic index has two entrances. The first (vertical) discriminates the prevailing hydrological conditions: if the samples are taken during "winter" the left entrance should be selected; if samples are taken during "summer" the right entrance should be used. The second entrance (horizontal) lists the taxa in an increasing order of tolerance in five classes: clean conditions (index value 5), mild stressing conditions (index value 4), intermediate stressing conditions (index value 3 ), strong stressing conditions (index value 2 ) and extreme conditions (index value 1) (Table 1).

After selecting the vertical entrance, the next step is to look for indicators of the first (clean) conditions. These are Ecdyonurus sp., Ephemerella sp., Leptophlebiidae, Plecoptera or Oulimnius sp. in "winter" or just Leptophlebiidae in "summer". A taxon is considered only when at least five specimens are present. When no indicators of the first category are found, we move to the following line in the table. The discrimination among water quality classes is more difficult in "summer". Therefore some taxa (e.g. Atyaephyra) are indicators of intermediate conditions. 


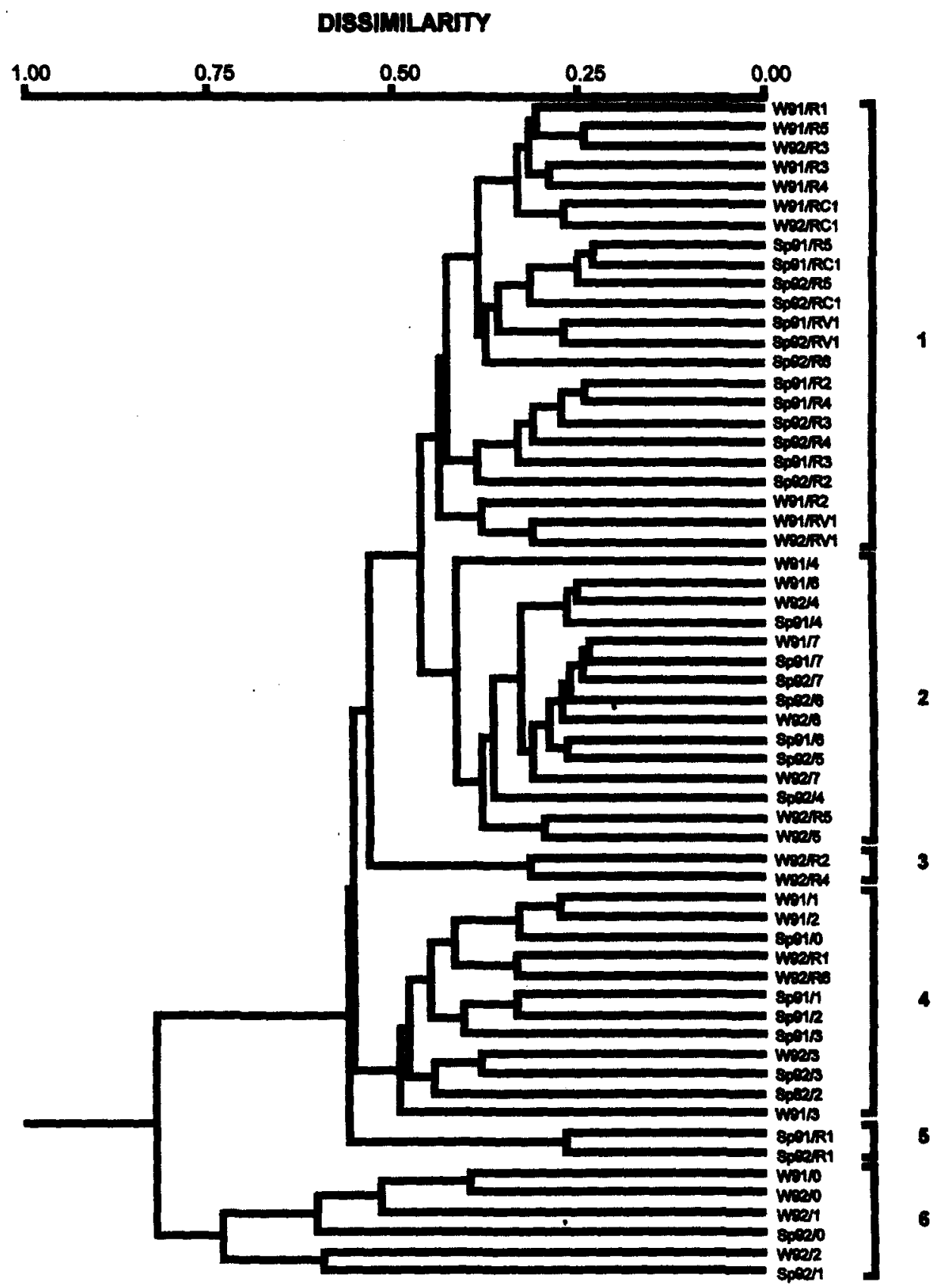

Fig. 1. Cluster analysis (UPGMA, Q mode, Bray-Curtis coeficient, $\log _{10}(x+1)$ transformation) for "winter" data set. $\mathrm{W}=$ winter, $\mathrm{Sp}=$ spring; 91 and 92 = sampling year; number after bar = sampling site. Cophenetic correlation coefficient $=0.89$.

\section{Validation of the Biotic index}

The Biotic index was validated with samples collected eight times from 1993 to 1994 , according the criteria: (1) correlation and stepwise multiple regression (Zar, 1984) with the physico-chemical variables significantly affected by the effluent (Mann-Whitney $U$ test; Zar, 1984) and (2) application of correspondence analysis (CA; Hill, 1973) to investigate if impacted and clean sites were discriminated along an ordination axis; and whether the index was correlated (product-moment coefficient; Zar, 1984) with the axis.

\section{RESULTS}

\section{Site cluster analysis}

The effluent discharge caused a significant decrease in the dissolved oxygen in the water and a significant increase in $\mathrm{pH}$, conductivity, sulphates and nitrates (Table 2). In terms of particle size no major changes were observed upstream and downstream of the effluent output. In all sites there were 


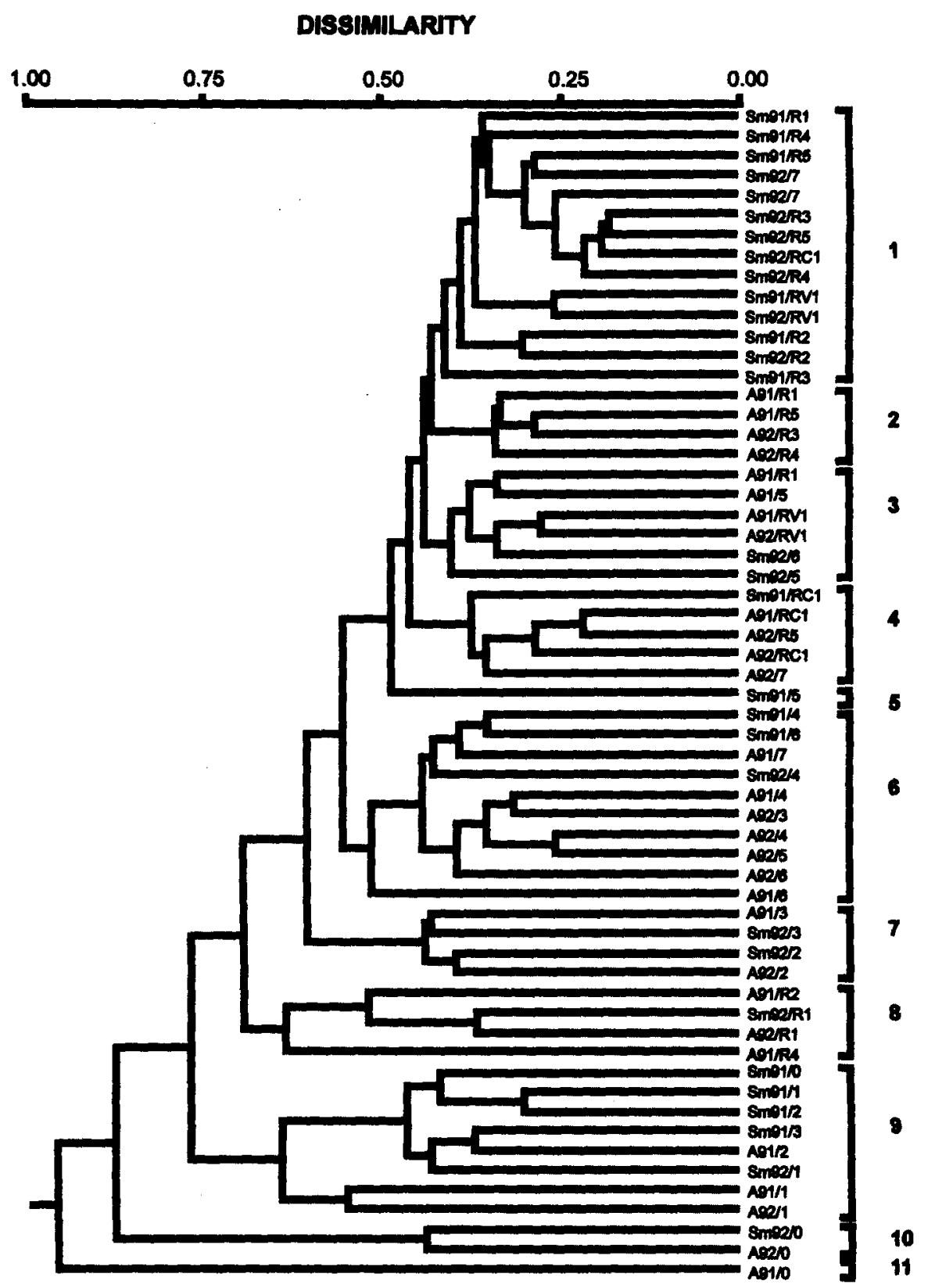

Fig. 2. Cluster analysis (UPGMA, $Q$ mode, Bray-Curtis coefficient, $\log _{10}(x+1)$ transformation) for "summer" data set. $\mathrm{Sm}=$ summer, $\mathrm{A}=$ autumn; 91 and $92=$ sampling year; number after bar $=$ sampling site. Cophenetic correlation coefficient $=0.89$.

stony and sandy substrates ( $>55 \%$ of sediment particles $>4 \mathrm{~mm}$ ) and submersed macrophytes. The exception was site 0 where the substrate particles were very fine $(50 \%$ of sediment particles between 0.5 and $1 \mathrm{~mm}$ ).

Changes in the environmental parameters were reflected by changes in the number of macroinvertebrate taxa in "winter", but not in "summer" (Table 2). Cluster analysis segregated impacted from reference sites either in "winter" (Fig. 1) and in "summer" (Fig. 2). In "winter" six groups of samples were identified; except for three samples, all reference sites were clustered in groups 1,3 and 5 whereas sites located below the effluent output were distributed in groups 2, 4 and 6 (Table 3). In "summer" 11 groups of samples were identified; reference sites were grouped in four clusters $(1,2,4,8)$, heavily impacted sites were grouped in four clusters (7, $9,10,11)$ and intermediate impacted sites were grouped in three clusters $(3,5,6)$ (Table 4 ). 
Table 3. Mean values of physico-chemical parameters for the site groups from cluster analysis for "winter" data set (1991, 1992). Standard deviation and number of observations are shown in parentheses. White: reference sites; black: sites located nearby the effluent output; grey: sites located further downstream of the effluent output; light grey: sites located downstream, far from the effluent output

\begin{tabular}{|c|c|c|c|c|c|c|c|c|}
\hline Group & $\begin{array}{l}\text { D.O. } \\
\text { (\%sat) }\end{array}$ & $\mathrm{pH}$ & $\begin{array}{l}\text { Conductivity } \\
(\mu \mathrm{S} / \mathrm{cm})\end{array}$ & $\begin{array}{l}\text { Sulphates } \\
\text { (mg/L) }\end{array}$ & $\begin{array}{c}\text { Nitrates } \\
(\mathrm{mg} / \mathrm{L})\end{array}$ & $\begin{array}{l}\text { Phosphates } \\
\text { (mg/L) }\end{array}$ & $\begin{array}{l}\text { Copper } \\
(\mathrm{mg} / \mathrm{L})\end{array}$ & $\begin{array}{l}\text { Iron } \\
(\mathrm{mg} / \mathrm{L})\end{array}$ \\
\hline 1 & $\begin{array}{l}102.3 \\
\quad(14.9 / 11)\end{array}$ & $\begin{array}{ll}7.9 & \\
& (0.5 / 16)\end{array}$ & $(118 / 10)$ & $\begin{array}{l}34.9 \\
\quad(10.9 / 10)\end{array}$ & $\begin{array}{l}0.15 \\
\quad(0.42 / 10)\end{array}$ & $\begin{array}{l}0.11 \\
(0.01 / 10)\end{array}$ & $\begin{array}{l}0.015 \\
\quad(0.008 / 10)\end{array}$ & $\begin{array}{l}0.324 \\
\quad(0.191 / 10)\end{array}$ \\
\hline$y^{2}+x^{2}+x^{2}$ & $\begin{array}{ll}96.9 & \\
& (5.6 / 7)\end{array}$ & $(0.2 / 9)$ & (376/9) & $\begin{array}{l}295.1 \\
\quad(131.8 / 9)\end{array}$ & $\begin{array}{l}16.26 \\
\quad(16.49 / 9)\end{array}$ & $\begin{array}{ll}0.11 & \\
& (0.02 / 9)\end{array}$ & $\begin{array}{l}0.013 \\
\quad(0.006 / 9)\end{array}$ & $\begin{array}{l}0.254 \\
\quad(0.127 / 9)\end{array}$ \\
\hline 3 & (12) & (/2) & (12) & (/2) & (12) & (12) & 0.004 & (/2) \\
\hline & $\begin{array}{l}69.7 \\
\quad(23.1 / 7)\end{array}$ & $\begin{array}{ll}7.7 & \\
& (0.4 / 13)\end{array}$ & $(882 / 9)$ & $\begin{array}{l}393.4 \\
\quad(294.2 / 5)\end{array}$ & $\begin{array}{l}20.76 \\
\quad(18.85 / 5)\end{array}$ & $\begin{array}{l}0.15 \\
\quad(0.04 / 5)\end{array}$ & $\begin{array}{l}0.031 \\
\quad(0.018 / 9)\end{array}$ & $\begin{array}{l}0.220 \\
(0.103 / 5)\end{array}$ \\
\hline 5 & (12) & (/2) & (/1) & (/1) & (/1) & 0.12 & (/1) & 0.220 \\
\hline & $\begin{array}{l}56.8 \\
\quad(18.0 / 5)\end{array}$ & $(0.6 / 5)$ & $(80 / 5)$ & $\begin{array}{r}688.6 \\
\quad(80 / 5)\end{array}$ & $\begin{array}{l}44.20 \\
\quad(43.8 / 5)\end{array}$ & $\begin{array}{l}0.20 \\
\quad(18.20 / 5)\end{array}$ & $\begin{array}{l}0.048 \\
\quad(0.052 / 5)\end{array}$ & $\begin{array}{l}0.112 \\
(0.090 / 5)\end{array}$ \\
\hline
\end{tabular}

Nodal analysis-bioindicators

Using cluster analysis we identified 18 and 20 groups of taxa in "winter" and "summer" data sets, respectively (see Appendix).

For both hydrological periods, most of the taxa groups had a clear high to moderate fidelity for one or several site groupings. e.g. in "winter", taxa group 15 which includes the ephemeropterans Ecdyonurus aurantiacus, Ephemerella cf. ignita and Leptophlebiidae (2 spp.) and the Coleoptera Oulimnius rivularis had a moderate fidelity for sampling group 1, which includes almost all refer-

Table 4. Mean values of physico-chemical parameters for the site groups from cluster analysis for "summer" data set (1991, 1992). Standard deviation and number of observations are shown in parentheses. White: reference sites; black; sites located nearby the effluent output; grey: sites located further downstream of the effluent output; light grey: sites located downstream, far from the effluent output

\begin{tabular}{|c|c|c|c|c|c|c|c|c|}
\hline Group & $\begin{array}{l}\text { D.O. } \\
\text { (\%sat) }\end{array}$ & $\mathrm{pH}$ & $\begin{array}{c}\text { Conductivity } \\
(\mu \mathrm{S} / \mathrm{cm})\end{array}$ & $\begin{array}{c}\text { Sulphates } \\
(\mathrm{mg} / \mathrm{L})\end{array}$ & $\begin{array}{l}\text { Nitrates } \\
(\mathrm{mg} / \mathrm{L})\end{array}$ & $\begin{array}{c}\text { Phosphates } \\
(\mathrm{mg} / \mathrm{L})\end{array}$ & $\begin{array}{l}\text { Copper } \\
(\mathrm{mg} / \mathrm{L})\end{array}$ & $\begin{array}{c}\text { Iron } \\
(\mathrm{mg} / \mathrm{L})\end{array}$ \\
\hline 1 & $\begin{array}{r}92.3 \\
\quad(19.0 / 12) \\
\end{array}$ & $\begin{array}{l}8.4 \\
\quad(0.8 / 12)\end{array}$ & $(274 / 12)$ & $\begin{array}{r}73.1 \\
\quad(98.2 / 12)\end{array}$ & $\begin{array}{l}0.32 \\
(0.30 / 12)\end{array}$ & $\begin{array}{l}0.38 \\
(0.47 / 12)\end{array}$ & $\begin{array}{l}0.023 \\
(0.021 / 6)\end{array}$ & $\begin{array}{l}0.392 \\
\quad(0.281 / 5)\end{array}$ \\
\hline 2 & $\begin{array}{r}101.0 \\
(17.7 / 4)\end{array}$ & $\begin{array}{ll}8.4 & \\
& (0.3 / 4)\end{array}$ & 785 & $\begin{array}{rr}84.8 & \\
& (42.5 / 4) \\
\end{array}$ & $\begin{array}{ll}0.53 & \\
& (0.25 / 4)\end{array}$ & $\begin{array}{l}0.74 \\
\quad(0.72 / 4)\end{array}$ & $\begin{array}{l}0.015 \\
(0.005 / 4)\end{array}$ & $\begin{array}{r}0.763 \\
\quad(0.573 / 4)\end{array}$ \\
\hline y & $\begin{array}{rr}96.5 & \\
& (10.5 / 6) \\
\end{array}$ & $\begin{array}{rr}7.8 & \\
& (0.3 / 6) \\
\end{array}$ & 1879 & $\begin{array}{r}395.3 \\
(459.6 / 6)\end{array}$ & $\begin{array}{r}9.81 \\
(13.68 / 6) \\
\end{array}$ & $\begin{array}{l}0.19 \\
(0.13 / 6)\end{array}$ & $\begin{array}{r}0.020 \\
(0.006 / 6)\end{array}$ & $\begin{array}{r}0.238 \\
(0.165 / 6)\end{array}$ \\
\hline 4 & $\begin{array}{r}107.2 \\
(17.5 / 6)\end{array}$ & $\begin{array}{ll}8.8 & \\
& (0.6 / 6)\end{array}$ & $(542 / 6)$ & $\begin{array}{l}157.0 \\
(113.7 / 6)\end{array}$ & $\begin{array}{ll}0.72 & \\
& (0.38 / 6)\end{array}$ & $\begin{array}{ll}0.29 & \\
& (0.20 / 6)\end{array}$ & $\begin{array}{r}0.015 \\
(0.005 / 5)\end{array}$ & $\begin{array}{l}0.323 \\
(0.132 / 5)\end{array}$ \\
\hline & 87.0 & 6.5 (/1) & 2520 & $\begin{array}{r}1035.0 \\
(/ 1)\end{array}$ & $\begin{array}{r}9.68 \\
\end{array}$ & 0.20 & & \\
\hline & $\begin{array}{r}84.9 \\
\quad(13.4 / 10) \\
\end{array}$ & $\begin{array}{r}7.2 \\
(0.5 / 10) \\
\end{array}$ & $(453 / 10)$ & $\begin{array}{r}1129.0 \\
\quad(149.8 / 10) \\
\end{array}$ & $\begin{array}{r}31.65 \\
\quad(27.46 / 10) \\
\end{array}$ & $\begin{array}{r}0.32 \\
\quad(0.18 / 10) \\
\end{array}$ & $\begin{array}{r}0.023 \\
(0.010 / 8) \\
\end{array}$ & $\begin{array}{l}0.175 \\
\quad(0.135 / 8) \\
\end{array}$ \\
\hline & $\begin{array}{r}45.8 \\
\quad(16.0 / 4) \\
\end{array}$ & $\begin{array}{l}7.5 \\
\quad(0.9 / 4) \\
\end{array}$ & $(276 / 4)$ & $\begin{array}{r}1039.5 \\
(69.1 / 4) \\
\end{array}$ & $\begin{array}{r}77.25 \\
(15.34 / 4) \\
\end{array}$ & $\begin{array}{rr}0.24 & \\
& (0.11 / 4) \\
\end{array}$ & $\begin{array}{r}0.023 \\
\quad(0.008 / 4) \\
\end{array}$ & $\begin{array}{l}0.050 \\
\quad(0.024 / 4) \\
\end{array}$ \\
\hline 8 & $\begin{array}{l}76.0 \\
\quad(21.5 / 4) \\
\end{array}$ & $\begin{array}{ll}8.2 & \\
& (0.6 / 4) \\
\end{array}$ & $(234 / 4)$ & $\begin{array}{rr}47.3 \\
\quad(29.5 / 4) \\
\end{array}$ & $\begin{array}{r}3.40 \\
\quad(4.60 / 4) \\
\end{array}$ & $\begin{array}{ll}.01 & \\
& (0.70 / 4) \\
\end{array}$ & $\begin{array}{r}0.023 \\
\quad(0.004 / 4) \\
\end{array}$ & $\begin{array}{r}1.215 \\
\quad(0.422 / 4) \\
\end{array}$ \\
\hline & $\begin{array}{l}47.0 \\
\quad(19.1 / 8) \\
\end{array}$ & $\begin{array}{l}8.7 \\
\quad(1.55 / 8) \\
\end{array}$ & 2906 & $\begin{array}{r}1184.6 \\
\quad(106.4 / 8) \\
\end{array}$ & $\begin{array}{r}45.30 \\
\quad(19.40 / 8)\end{array}$ & $\begin{array}{rr}0.92 & \\
& (0.60 / 8) \\
\end{array}$ & $\begin{array}{r}0.023 \\
\quad(0.008 / 4) \\
\end{array}$ & $\begin{array}{l}0.030 \\
\quad(0.016 / 4)\end{array}$ \\
\hline & 84.0 & $\begin{array}{rr}11.2 \\
\quad(/ 2) \\
\end{array}$ & 3335 & $\begin{array}{r}1007.0 \\
\quad(/ 2) \\
\end{array}$ & $\begin{array}{l}64.95 \\
\\
\end{array}$ & 0.29 & $\begin{array}{rr}0.030 \\
\\
\end{array}$ & $\begin{array}{r}0.040 \\
\quad(12) \\
\end{array}$ \\
\hline & 71.0 & 8.0 & 2390 & 1141.0 & 38.90 & 0.60 & 0.20 & 0.060 \\
\hline
\end{tabular}




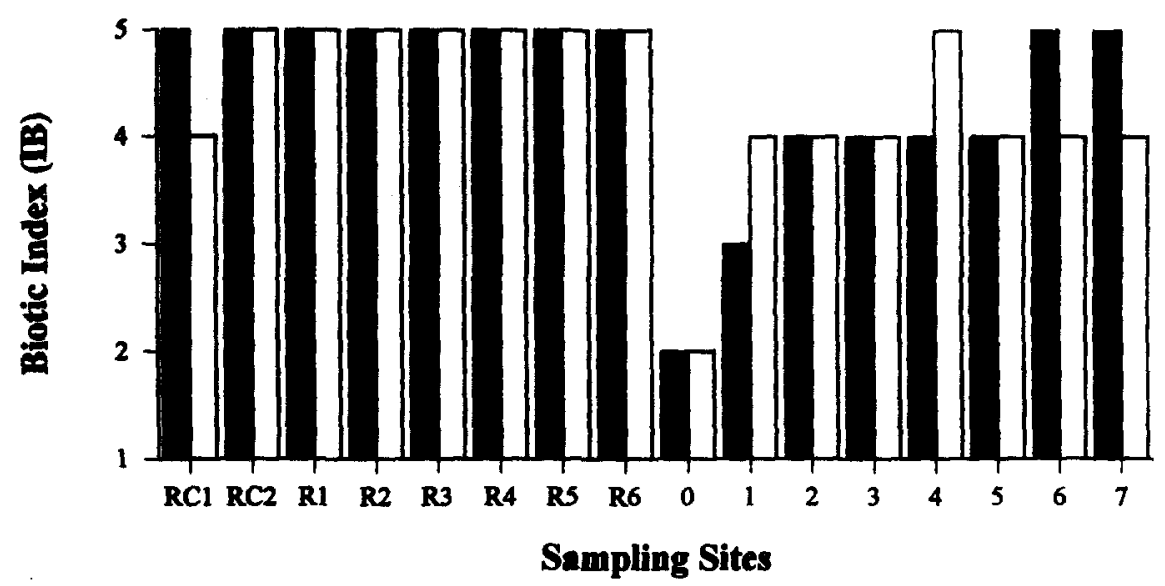

Fig. 3. Mean biotic index (IB) values for the "winter" (black bars) and "summer" (white bars) periods from 1993 to 1994 , along the studied river.

ence sites. taxa groups 2, 3 and 5, which includes Physa acuta, Libellulidae, Berosus affinis, Chironomus thummi/plumosus, Culicidae, and the atmospheric breathing coleopterans and heteropterans Helophoridae, Ochthebius sp., Hydrobiidae, Gerris sp. and Hydrometra sp. had a moderate fidelity for the site group 4, which includes some of the strongly impacted sites: 1-3. This affinity relationship between groups of taxa and groups of sites, was used to identify the indicators for the biotic index table.

Indicators of clean conditions were taxa absent from the impacted sites. e.g., all plecopterans (taxa group 17) and the cased trichopterans Leptoceridae (taxa group 18). As a consequence, the fidelity relationships with site groups 4 and 6 (sites 0-3) were negative. However, the same was not true for the tolerant taxa. e.g. Chironomus thummi/plumosus (taxa group 3) was very common in the most severely perturbed areas which resulted in a high fidelity for site group 6 (effluent output), but was also present in high densities in reference sites, especially in "summer" in the smaller and shallower ponds. In this period, Chironomus thummi/plumosus was clustered in taxa group 7 (see Appendix), and no negative fidelity was observed with some reference sites (e.g. site groups 1 and 3). Therefore, for the elaboration of the water quality table, more important than the presence of tolerant taxa was the presence of indicators of clean conditions.

\section{Index validation}

For the 8 sampling periods between 1993 and 1994, the index was able to discriminate among clean, intermediate and very impacted conditions (Fig. 3). CA analysis (Fig. 4) discriminated, along the first axis, clean (Group A) from impacted sites (Groups B and C), either in "summer" and "winter". Moreover, the index was significantly correlated with the 1st $\mathrm{CA}$ axis (Table 5) and with the variables more affected by the effluent: conductivity, sulphates, nitrates, $\mathrm{pH}$ and dissolved oxygen (Table 6).

Changes in the biotic index along the river were consistent with changes in the water chemistry. Stepwise multiple regression analyses (Table 6) suggests that, among the chemical parameters analysed, nitrates (all year), pH ("winter") and conductivity ("summer") were the parameters with higher contribution to the changes in the Biotic Index.

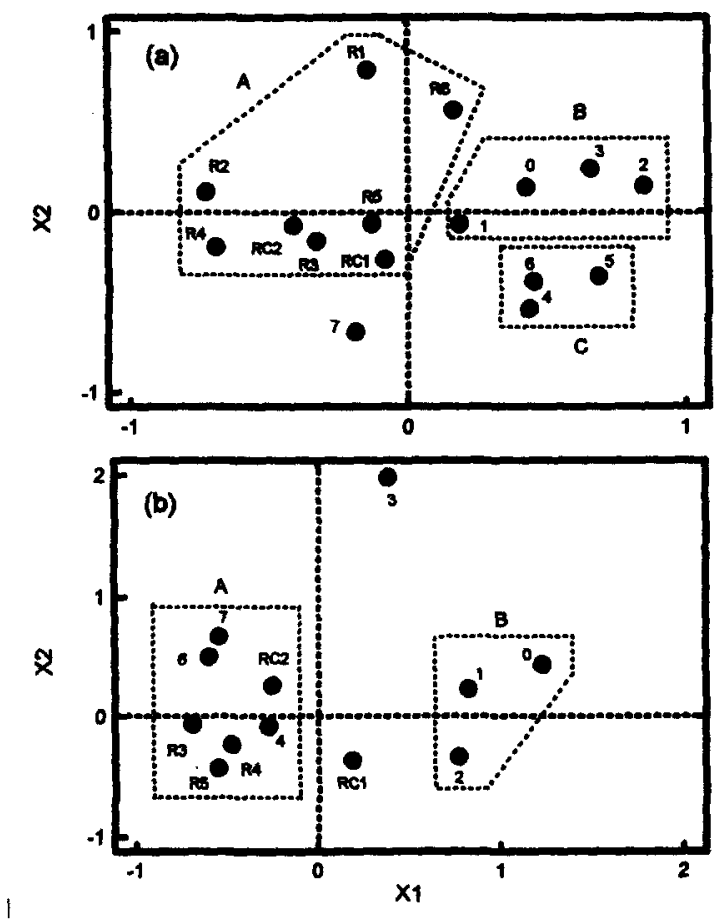

Fig. 4. Correspondence analysis for winter (a) and summer (b) data sets (1994). $\mathrm{R}=$ reference sites; $0-7$ sites located downstream the effluent output. 
Table 5. Correlations (product-moment coefficient) between CA axes 1 and the Biotic Index (IB), dissolved oxygen, pH, conductivity, sulphates and nitrates for the 8 sampling periods $(1993,1994) *=P<0.05 ; * *=P<0.01 ; * *=P<0.001$

\begin{tabular}{|c|c|c|c|c|c|c|}
\hline CA axis 1 & IB & DO (\%sat) & $\mathrm{pH}$ & $\begin{array}{c}\text { Conductivity } \\
(\mu \mathrm{S} / \mathrm{cm})\end{array}$ & Sulphates $(\mathrm{mg} / \mathrm{L}$ ) & Nitrates (mg/L) \\
\hline winter 1993 & $-0.592^{*}$ & -0.233 & -0.228 & $0.680 * *$ & $0.709 * *$ & 0.431 \\
\hline spring 1993 & $-0.620^{*}$ & -0.315 & 0.073 & $0.659 * *$ & $0.683 * *$ & $0.523^{*}$ \\
\hline spring 1994 & $-0.599^{*}$ & -0.138 & -0.203 & $0.713^{* *}$ & $0.682^{* *}$ & $0.583^{*}$ \\
\hline summer 1993 & $-0.958 * * *$ & -0.081 & $0.713^{* *}$ & $0.657^{* *}$ & $0.631^{* *}$ & - \\
\hline autumn 1994 & $-0.904^{* * *}$ & -0.477 & 0.495 & $0.780 * *$ & $0.734 * *$ & $0.830^{* * *}$ \\
\hline
\end{tabular}

\section{DISCUSSION}

Studies in South Portuguese rivers are scarce. However, the overall conclusion of these studies is that the shifting between lotic and lentic conditions during the year dictates a high dynamism in some environmental parameters such as suspended solids, conductivity, hardness, etc. (Pinto, 1994; Morais, 1995). These dynamics have also been observed in the major energy sources and dominance in major algal, macrophyte and macroinvertebrate groups (Pinto, 1994; Morais, 1995).

Another characteristic of these streams is that the time of shifting between lotic-lentic conditions is unpredictable. The reophilic/limnephilic elements may remain during the transitional shift in hydrological conditions. Moreover, although the rivers normally have flow during "winter", this flow is not continuous. Besides some peak discharges after heavy rain, the rivers may retain their "lentic" aspect with visible flow only at shallow areas. This results in (a) the presence of limnephilic elements during all year and (b) an inconspicuous longitudinal gradient. In our particular study, the continuous discharge of the effluent in "summer" creates some flowing conditions between pools creating conditions for the presence of reophilic species. This was particularly true for Simuliidae and Hydropsyche spp. Because the small current occurs only downstream from the discharge point, these species had a negative fidelity with reference sites.

The seasonal alterations on Mediterranean streams imply sequences of recolonizations; a process in which species may differ in their tolerance levels to some environmental factors and, presumably to pollution. This modality of double response of the communities was incorporated in the index: there are two sets of environmental condition indicators, according to the season.

Traditionally, reophilic species have a prominent status in biological indices. These species are highly dependent on oxygen, current and substrate particle size (De Pauw and Vanhooren, 1983; Verneaux et al., 1982). In this category we may include all Plecoptera and some Ephemeroptera and Trichoptera. During winter, streams in South Portugal are inhabited by reophilic communities and the species replacement, as a consequence of decreases in water quality, is similar to that observed elsewhere: elimination of the most of Plecoptera, Ephemeroptera and Trichoptera groups. This leads to the increase in species more tolerant and generally associated with limnephilic or lentic conditions: tolerant to low oxygen concentrations, fine substrate particle size, etc.

In the present case, the pollution tolerant taxa in "summer" can be classified in two categories: (a) taxa with the capacity to take oxygen from the water even at low concentrations (e.g. "red" Chironomidae) and (b) taxa breathing atmospheric oxygen (e.g. many coleopterans and heteropterans). This suggests that oxygen is a major perturbing effect. However, atmospheric breathing Coleoptera and Heteroptera have another characteristic which may explain their presence in the very impacted sites: they are generally "isolated" from the water by an air film. Their contact with the water (and therefore with pollutants) is therefore minimum.

The nodal analysis also identified elements of Neuston as having a high fidelity with the most polluted sites. It is plausible that this could be an indirect effect related to the absence of potential predators (e.g. fish) in these areas. However,

Table 6. Correlations (product-moment coefficient) between the Biotic Index (IB) and dissolved oxygen, pH, conductivity, sulphates and nitrates for the "winter" and "summer" data sets and stepwise regression analysis $(1993,1994)$

\begin{tabular}{llllll}
\hline & DO (\%sat) & pH & Conductivity ( $\mu$ S/cm) & Sulphates (mg/L) & Nitrates (mg/L) \\
\hline IB "winter" & $0.455^{* * *}$ & $-0.805^{* * *}$ & $-0.484^{* * *}$ & $-0.578^{* * *}$ & $-0.610^{* * *}$ \\
IB "summer" & $0.285^{* *}$ & $-0.311^{*}$ & $-0.605^{* * *}$ & $-0.570^{* * *}$ & $-0.550^{* * *}$ \\
\hline
\end{tabular}

Stepwise regression equations:

"winter": 10.36-0.74 [pH]-0.15 [nitrates]; $\mathbf{R}^{2}=0.737 ; \mathrm{F}=89.27^{\text {**** }}$

"summer": 7.34-0.32 [conductivity]-0.15 [nitrates]; $\mathrm{R}^{2}=0.539 ; \mathrm{F}=23.80^{* * *}$ 
because they live at water surfaces, they were not included in the reference table.

Chironomus thummi / plumosus were associated with strong stressing conditions in "winter". However, a high fidelity for some reference sites was also observed in this period. This taxa feeds on benthic organic matter and therefore are favoured by the accumulation of this material in the lentic facies of the river. In "summer", Chironomus thummi/plumosus can be found all along the river and therefore they had a secondary position as bioindicator, although it is one of the last species which disappears when the conditions deteriorate.

The identification of good indicators is a difficult task because sensitivity of taxa may vary according to different phases of the life cycle (De Nicola et al., 1986), age (Jarboe and Romaire, 1991) or among populations (Münzinger and Monicelli, 1991). Moreover, taxa also differ in their sensibility to different stressors. e.g. Tipula abdominalis (Diptera) seems to be tolerant to acid pollution and heavy metals but intolerant to organic pollution; Mystacides sepulchralis (Trichoptera) and Ephemerella bicolor (Ephemeroptera) have been referred to as tolerant to heavy metals, but intolerant to acid stress (USEPA, 1990).

On a more broad scale, biotic interactions and environmental conditions such as temperature (Pilgrim and Burt, 1993) is also likely to affect survival and/or tolerance to stressing conditions. Therefore, the application of a biotic index developed for other geographical areas and for different pollution types may be questionable.

The difficult task is, therefore, to identify indicators of water quality under lentic conditions. Because biotic indices have been described for permanent running waters, the documentation of community changes under lentic conditions is almost absent.

Ideally, a biotic index should consider the particular stressing conditions under study, but the problem here is the identification of bioindicators. This obstacle may be overcome by the application of nodal analysis (sensu Boesch, 1977). Some ordination techniques such as DCA and $\mathrm{CA}$ are also potential tools for the identification of indicator species. However, ordination is more appropriate to identify gradients, rather than discrete groups or discontinuities. For the latter case it is preferable to use the application of classification techniques.

Some degree of subjectivity is introduced when identifying clusters because no strict rules have been drawn for this purpose. A criterion could be to stipulate a resemblance level to identify the clusters. However, the degree of resemblance depends on the similarity index used. On the other hand, the presence of rare species in some samples has the effect of decreasing the resemblance levels. Finally, samples with low numbers of species and individuals are likely to be segregated from all others. This can be easily illustrated by site cluster 6 (Fig.1) which comprises all but one site 0 samples.

The criterion used here was to look for consistent groups in terms of general dendrogram morphology and the inspection of nature of the grouped samples: e.g. groups 1 and 2 of the "winter" cluster (Fig. 1) are clearly different; the first group includes only reference sites whereas group 2 includes only sites located downstream of the effluent output.

The split of the reference sites among several clusters can be explained by: (1) natural differences among reference sites with plausible differences in macroinvertebrate assemblages; (2) the occasional presence of some taxa in large numbers, which is enough to decrease the similarity relatively to samples with more "standard" faunistic composition.

The identification of the "summer" clusters was less "clear cut". This may be related to the heterogeneity of the ponds. As the dry season advances ponds become smaller and shallower. With the high summer temperature, some macrophytes start decaying and anoxia conditions can be created at the sediment level. Under these "natural" perturbing conditions, some sensitive species may disappear. Consequently, the dissimilarity between some reference sites and some impacted sites decreases. The result is the presence of "reference site clusters" among "clusters of impacted sites".

Another difficulty is to determine when a particular "potentially impacted site" can be considered "recovered". This can be addressed by cluster analysis by inspecting whether a particular "downstream" site is clustered with the reference sites. In the present study, the last sampling site was generally associated with reference sites which included upstream sampling stations and equivalent downstream sampling sites in a reference, unpolluted river. This association (clustering) reflects the presence of many taxa common to the reference sites.

In our case study, in "summer" the effluent almost caused a total elimination of macroinvertebrates at the discharge point. The ordination analysis and the stepwise regression analysis suggest that the major factors affecting the aquatic assemblages were the conductivity (apparently caused by a high content of sulphates), nitrates, $\mathrm{pH}$ and, to a lesser extent, the oxygen. The first $\mathrm{CA}$ axis clearly discriminated impacted from reference sites in all sampling occasions. This first axis was, in general, significantly correlated with the variables more affected by the effluent discharge: conductivity, sulphates, nitrates. The first axes were also always correlated with the biotic index, suggesting that the index can be a reliable indicator of water quality in the studied system.

As expected, plecopterans were indicators of unpolluted conditions. These taxa are invariably indicators of clean conditions in any biotic index developed in Europe (e.g. BBI - De Pauw and 
Vanhooren, 1983; BMWP score system - Armitage et al., 1983). In summer, these taxa do not naturally occur in many intermittent Mediterranean rivers, which, according to other biological indices, is a misleading indicator of stress. As in other biotic indices, Chironomus thummi/plumosus was very abundant in the most impacted sites, suggesting that this group is in fact tolerant to a broad spectrum of stressors (see also USEPA, 1990).

As in other studies on temporary rivers, the environmental conditions experienced drastic changes along the year (e.g., Morais, 1995) suggesting that the inhabitants of the river may be under sub-optimal conditions during part of the year. Probably because of this, the indicator value of some taxa was not the same during all year. e.g., the shrimp Atyaephyra desmarestii was considered an indicator of clean/mild conditions in "summer", but a clear indicator of mild stressing conditions in "winter".

Biotic indices have been very popular because the complexity of changes in the structure of the biotic communities can be expressed in a numerical category. This is easily understandable for non biologists in charge of water quality control programs. The application of biotic indices is also easier and quicker than the application of other biological methods, including multivariate analysis. They are useful in routine programs but do not replace other measurements of stressing conditions (e.g. biodiversity or functional measurements).

Here we showed that nodal analysis can be an important tool for the identification of indicators of particular stressing conditions and, therefore, for the elaboration of biotic indices which can be applied to particular conditions.

Acknowledgements--This work was partially supported by JNICT through a grant to C. N. Coimbra (BM/2301/91/ RN). We thank three anonymous referees for critical comments on the manuscript.

\section{REFERENCES}

Alba-Tercedor J. and Sánchez-Órtega A. (1988) Un método rápido y simple para evaluar la calidad biológica de las águas corrientes basado en el de Hellawell (1978). Limnetica 4, 51-56.

A.P.H.A. (1980) Standard Methods for the Examination of Water and Wastewater. 15th ed. Americam Public Health Association, Washington.

Armitage P. D., Moss D., Wright J. F. and Furse M. T. (1983) The performance of a new biological water quality system based on macroinvertebrates over a wide range of unpolluted running- water sites. Wat. Res. 17 , 383-387.

Barton D. R. and Metcalfe-Smith J. L. (1992) A comparison of sampling techniques and summary indices for assessment of water quality in the Yamaska river, Québec, based on benthic macroinvertebrates. Environ. Monit. Assess. 21, 225-244.

Boesch D. F. (1977) Application of numerical classification in ecological investigation of water pollution.
Special Scientific Report 77, Virginia Institute of Marine Sciences, Gloucester Point.

Coimbra C. N. and Graça M. A. (in press) Water quality assessment based on the structure of macroinvertebrate communities: a comparison between methods. Verh. Internat. Ver. Limnol.

Coimbra C. N., Graça M. A. and Cortes R. M. (1996) The effects of a basic effluent on macroinvertebrate community structure in a temporary Mediterranean river. Environ. Pollut. 94, 301-307.

De Pauw N., Roels D. and Fontoura A. P. (1986) Use of artificial substrates for standardized sampling of macroinvertebrates in the assessment of water quality by the Belgian Biotic Index. Hydrobiologia 133, 237-258.

De Pauw N. and Vanhooren G. (1983) Method for biological quality assessment of watercourses in Belgium. Hydrobiologia 100, 153-168.

De Nicola G. M., Migliore L. and Gambardella C. (1986) Toxicity of mercury on different stages of the biological cycle of Asellus aquaticus (L) and Proasellus coxalis Dollf (Crustacea, Isopoda). Bull. Soc. It. Biol. 62, 321328.

Descy J. P. and Coste M. (1991) Methods for assessing water quality based on diatoms. Verh. Internat. Verein. Limnol. 24, 2112-2116.

Faith D. P., Minchin P. R. and Belbin L. (1987) Compositional dissimilarity as a robust measure of ecological distance. Vegetatio 69, 57-68.

Fontoura P. and Moura A. M. (1984) Effects of some industrial effluents in the biological quality of the water of the river Lima. Publ. Inst. Zool. Fac. Ciênc. Porto 184, 1-21.

Hill M. O. (1973) Reciprocal averaging: an eigenvector method of ordination. J. Ecol. 61, 237-249.

Jarboe H. H. and Romaire R. P. (1991) Acute toxicity of permethrin to four size classes of red swamp crayfish (Procambarus clarkii) and observations of post-exposure effects. Arch. Environ. Contam. Toxicol. 20, 337-342.

Krystiano A. I. A. and Kusjantono H. (1991) A preliminary study of the use of BBI (Belgian Biotic Index) to assess the water quality of the river Ledok, Indonesia. Conservation and Management of Tropical inland Waters: Problems, Solutions and Perpectives. September. 5-9. Hong Kong.

Legendre L. and Legendre P. (1979) Écologie Numérique. Vol. 2. Masson, Paris.

Metcalfe J. L. (1989) Biological water quality assessment of running waters based on macroinvertebrate communities: history and present status in Europe. Environ. Pollut. 60, 101-139.

Morais M. M. (1995) Organização Espacial e Temporal de um Rio Temporário Mediterrânico (Rio Degebe, Bacia Hidrográfica do Guadiana). Descritores físico-químicos e produtores primários. Comunidades bentónicas de macroinvertebrados. Ph.D. Thesis, University of Évora, Évora, Portugal.

Moreira M. H., Canha A. P., Franco O. M. and Moura A. M. (1988a) Comunidades de macroinvertebrados do rio Caima e do curso superior e médio do Vouga: cartografia da qualidade biológica da água. Rev. Biol. U. Aveiro 2, 41-85.

Moreira M. H., Engels H., Moura A. M., Franco O. M. and Canha A. P. (1988b) Aplicaçãode técnicas de análise multivariada ao estudo do efeito do efluente da fábrica de celulose do Caima sobre as comunidades de macroinvertebrados. Actas Col. Luso-Esp. Ecol. Bacias Hidrogr. e Rec. Zoológicos 287-295.

Münzinger A. and Monicelli F. (1991) A comparison of the sensivity of three Daphnia magna populations under chronic heavy metal stress. Ecotox. and Envir. Safety 22, 24-31.

Pilgrim W. and Burt M. D. B. (1993) Effect of acute pH depression on the survival of the freshwater amphipod 
Hyalella azteca at variable temperatures: field and laboratory studies. Hydrobiologia 254, 91-98.

Pinto P. N. S. L. (1994) Cinética de colonização das comunidades de macroinvertebrados de um rio temporário do Sul de Portugal (Rio Degebe, Bacia hidrográfica do Guadiana). Ph.D. Thesis, University of Evora, Évora, Portugal.

USEPA (United States Environmental Protection Agency) (1990) Macroinvertebrates Field and Laboratory Methods for Evaluating the Biological Integrity of Surface Waters. EPA/600/4-90/030. p. 256.
Verneaux J., Galmiche $P$, Janier $F$, and Monnot A. (1982) Une nouvelle méthode pratique d'évaluation de la qualité des eaux courantes. Un indice biologique de qualité biologique génerale (I.B.G.). Ann. Sci. Univ. Besançon, Biol. Anim.. tème sér. 3, 11-21.

Washington H. G. (1984) Diversity. biotic and similarity indices. A review with special relevance to aquatic ecosystems. Wat. Res. 18, 653-694.

Zar J. F. (1984) Biostatistical Analysis. Second ed. Prentice-Hall, Englewood Cliffs, N.J. 


\section{APPENDIX}

Taxonomic composition of taxa groups and their fidelity for site groups in "winter" (A) and "summer" (B). Both the taxa groups and the site groups were obtained by cluster analysis. Fidelity: High: $\geq 3$ (black); Moderate: 2-2.9 (grey); Low: 1-1.9 (light grey); Negative: < 1 (white).

\begin{tabular}{|c|c|c|c|c|c|c|}
\hline & \multicolumn{6}{|c|}{ Site Groaps } \\
\hline & & rence & & Impected + & Impactiod & Others \\
\hline Taxa Groups & 1 & 3 & 5 & 6 & 4 & 2 \\
\hline 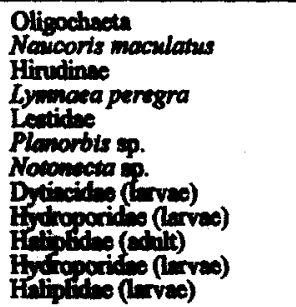 & & & & 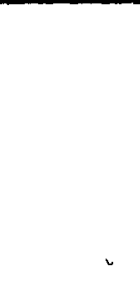 & & \\
\hline $\begin{array}{l}\text { Phyea acuta } \\
\text { Libellulidec }\end{array}$ & & & & & & \\
\hline 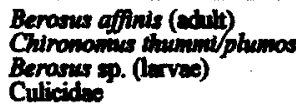 & & & & & & \\
\hline Chimencmini & & & & & & \\
\hline 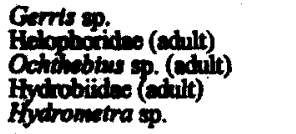 & & & & & & \\
\hline Coenegrionidec & & & & & & \\
\hline Trypodinge & & & & & & \\
\hline Corixides & & & & & & \\
\hline Buthynia tentaculata & & & & & & \\
\hline $\begin{array}{l}\text { Chamarra marginata } \\
\text { Fydropsyche sp. }\end{array}$ & & & & & & \\
\hline Platycnemiss sp. & & & & & & \\
\hline Simouliide: & & & & & & \\
\hline Other Diptere & & & & & & \\
\hline Ancyhus fluviattis & & & & & & \\
\hline $\begin{array}{l}\text { Ectyonurus auranitlacus } \\
\text { Ephemenella sp. } \\
\text { Loplophlobidide } \\
\text { Oullimentus sp. (larves) }\end{array}$ & & & & & & \\
\hline 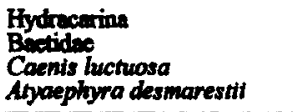 & & & & & & \\
\hline 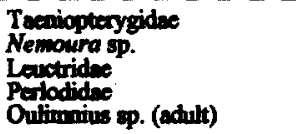 & & & & & & \\
\hline Leptoceridae & & & & - & & \\
\hline
\end{tabular}




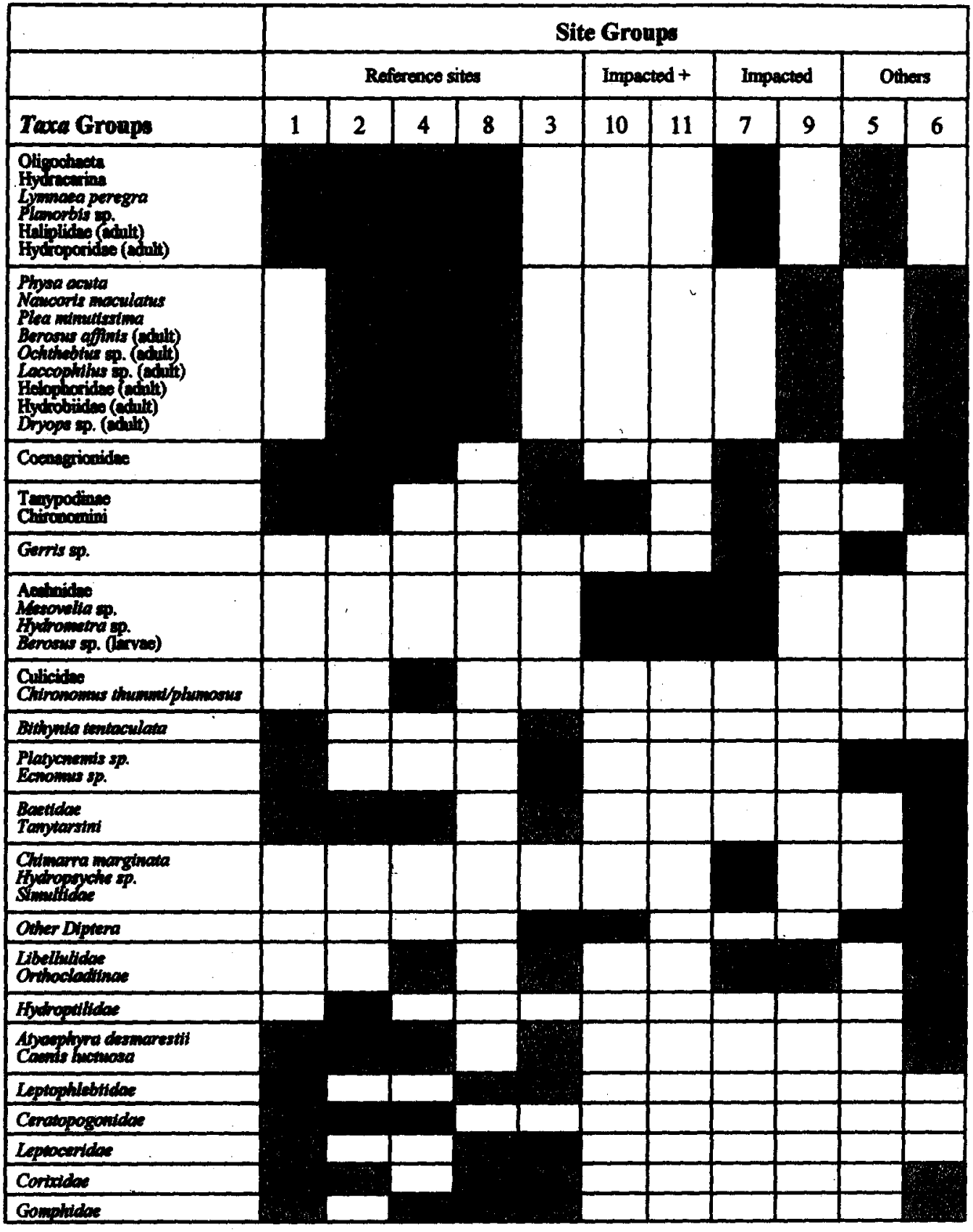

